最大耐力のばらつきが木造軸組建物の保有水平耐力, 最大変位応答に与之る影響

\title{
INFLUENCE OF THE MAXIMUM BEARING FORCE DISTRIBUTION TO THE ULTIMATE HORIZONTAL LOAD AND MAXIMUM DISPLACEMENT RESPONSE OF TRADITIONAL TIMBER HOUSES
}

\author{
山田耕司* \\ Koji YAMADA
}

\begin{abstract}
In this paper, I discuss the influence of the bearing force distribution on aseismatic performance of traditional timber houses. In order to discuss the distribution of bearing force in each wall, Monte Carlo simulation is employed. 208 exist houses are analyzed, and 100 analysis models are made in each house. The assumption of rigid floor and non-structural wall resistance force are also concerned. The results may be summarized as follows: the horizontal resistant forces calculated by deterministic models are the lower limit of the horizontal resistant forces of data spread models. The ratio of the maximum displacement response by data spread models over ones by deterministic model changes according to the type of an earthquake motion and its peak ground velocity.
\end{abstract}

Keywords : Traditional timber wooden house, Non-structural wall, Monte Carlo simulation, Maximum displacement response, Horizontal resistant force

軸組木造住宅, 雑壁, モンテカルロシミュレーション, 最大変位応答, 保有水平耐力

\section{1. 序}

構造設計者が体頼者に構造性能を説明する場合，通常は確定的に 設定された解析モデルの数值計算結果を用いる。しかし，たとえ同 一の設計であっても，建物の構造性能にばらつきが生じるのは，自 明のことである.この場合, 体頼者に対して, 建物性能のばらつき を説明することも必要であろうが，現在までにそのような資料は示 されていない，木造住宅では，壁量により構造性能を比較すること が可能である．しかし，同じ壁量充足率であっても，壁配置の偏心 や雑壁の影響, 耐力壁の耐力のばらつきにより，粠造性能のばらつ きが大きく生じると考えられる．そこで壁配㯰，雑壁・耐力壁の耐 力特性のばらつきを考虑した計算を行い，その構造性能のばらつき が示されていることは，構造設計者と依頼者のコミュニケーション を円滑にするために重要と考える：これまで，著者は，多数の既存 建物の設計図書から床剛性と雑壁を考慮した解析モデルを作成し， 保有水平耐力を求め, 保有水平耐力と壁量の関係を示し，保有水平 耐力の简易予測法を提案した ${ }^{1)}$ 。また，既報では，雑壁や床剛性を 考虑した最大変位応答を耐力壁線の仮定無しに計算し，壁量・保有 水平耐力との関倸を示すと共に，最大変位応答の簡易予測法を検討 した. その結果， 4 隅火打ちの床でも剛床仮定を行っても良いこと が判明した ${ }^{2)}$. 一方で, 耐力壁の復元力特性には, 大きなばらつき
があり 3), 同じ建物を建てたとしても，同じ性能を示す保証は無い. 木造住宅の耐力壁・雑壁の総数を考えれば，中心極限定理により保 有水平耐力は推定可能とも考えられるが，実際には，耐力壁が 2 3 枚程度しかない構面も存在するため, 理論計算よりばらつく可能 性がある. また, 耐力壁などの総数も木造住宅の床面積により大き く異なる，そこで，本報では，実際の建物において，個々の耐力要 素の最大耐力のバラツキを考慮した際の保有水平耐力と最大変位応 答のばらつきを数値解析により論じる.

\section{2. 各種仮定・使用する既存建物の壁量 \\ 2. 1 建物モデルの仮定}

本報では, 図 1 に示すように壁要素と床要素で構成された疑似 3 次元モデルである。この解析モデルは, 耐力壁, 雑壁を耐震要素と 考え，その耐力特性に応じた等価せん断バネを図 2 のように仮定し た，具体的な解析事例を図 3 に示寸，床は，剛床仮定を用いる．

階高は，2700mm としている，建物質量と回転慣性は表 1 に基づ いて計算した。

解析では，耐力壁および雑壁の最大耐力を正規分布で分布すると して，各耐力壁・雑壁ごとに最大耐力を設定し，1つの建物平面プ ランに対して， 100 例の耐力壁・雑壁の最大耐力分布の異なる解

* 豊田工業高等専門学校建築学科 助教授・博士(工学) 
析モデルを作成した（建物平面プランは 208 棟あるので, 20800 棟の 計算を行っている）。 なお，本解析と比較するため, 壁量計算に基 づいて壁耐力を確定值とした解析モデルによる計算も行っている （以下，“壁量計算に基づいた確定論”むしくは単に“確定論”之 称する）。この場合は, 図 4 に示す “確定論” の復元力特性を用い ている.

壁実長 $910 \mathrm{~mm}$ 以上の耐力壁・雑壁は, $910 \mathrm{~mm}$ 程度の壁が連続し て設固されていると仮定し, 次のルールにより複数の壁に分割した. 耐力壁は, 壁実長 $1450 \mathrm{~mm}$ 以下を 1 枚の壁と考え, 壁赛長 $1450 \mathrm{~mm}$ を超える場合は, $910 \mathrm{~mm}$ 毎に壁を分割した（例えば，壁実長 $2300 \mathrm{~mm}=910 \mathrm{~mm}+1390 \mathrm{~mm}$ の 2 ヶの壁とする). 実際は壁実長 $1800 \mathrm{~mm}$ の耐力壁も存在したが, 本報では壁実長 $910 \mathrm{~mm}$ を標準と考える.

雑壁は無開口壁のみを対象とし, 垂壁, 腰壁は雑壁に算入しない. また, 雑壁は大壁形式, 外周壁においては片面貼り, 内壁において は両面貼りと仮定した. 雑壁も, 耐力壁の場合と同様に, 壁実長

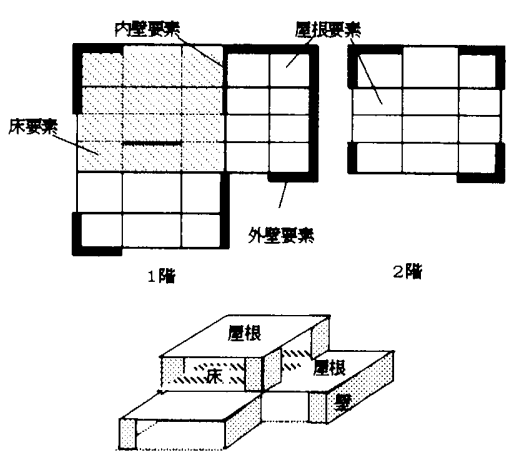

図 1 建物解析モデル例

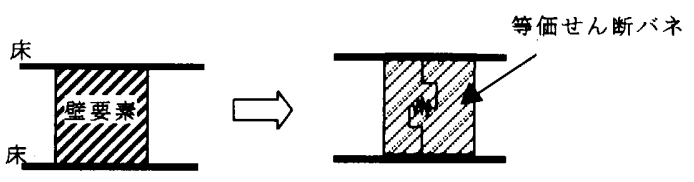

図 2 壁のモデル化
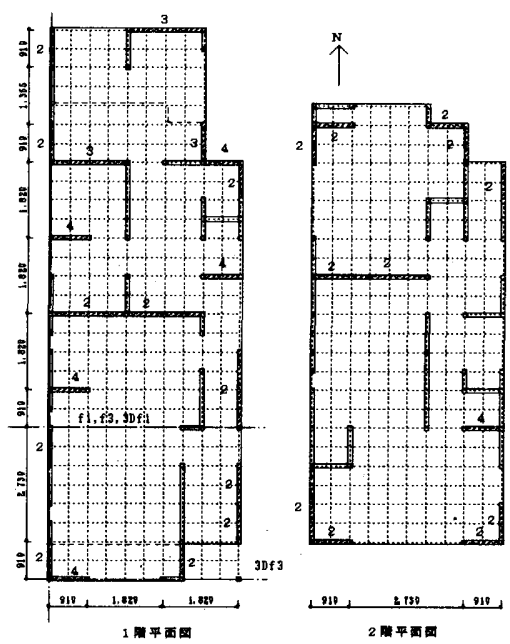

図 3 壁配置の具体的事例（3．1 節の計算建物）
$910 \mathrm{~mm}$ ごとに 1 つの雑壁としてまとめ, 端数( $900 \mathrm{~mm}$ 末満)も雑壁と して算入した（例えば，壁実長 $2300 \mathrm{~mm}=910 \mathrm{~mm}+910 \mathrm{~mm}+480 \mathrm{~mm}$ の 3 ヶの壁とする）。

\section{2 壁および床の骨格曲線と復元力特性}

図 4 に文献 4)に基づく壁 $1 \mathrm{~m}$ 当たりの骨格曲線, 復元力特性を示 す.この履歴モデルは文献 4)の Bilinear 型バネと Slip 特性を持つ Tri-linear 型バネの並列バネであり，一方向の最大耐力を越える経䀫 最大変位を正負両方向の変位で共有している. また，除荷時は，第 1 㓮性で除荷されるものとしている.

表 1 建物質量の仮定

\begin{tabular}{|l|l|l|}
\hline 項目 & 質量 & 備考 \\
\hline 重い屋根 & $90 \mathrm{~kg} / \mathrm{m}^{2}$ & 施行令を参考 (軒の深さは $0.75 \mathrm{~m}$ とする) \\
\hline 軽い屋根 & $60 \mathrm{~kg} / \mathrm{m}^{2}$ & 施行令を参考（軒の深さは $0.75 \mathrm{~m}$ とする) \\
\hline 外壁 & $190 \mathrm{~kg} / \mathrm{m}$ & サイディング+軸組+ボード内壁 \\
\hline 内壁 & $95 \mathrm{~kg} / \mathrm{m}$ & $\begin{array}{l}\text { ボード内壁+軸組+ボード内壁 } \\
\text { (雑壁長は壁実長の2 倍になる) }\end{array}$ \\
\hline 床 & $50 \mathrm{~kg} / \mathrm{m}^{2}$ & 施行令を参考 \\
\hline 樻载物 & $60 \mathrm{~kg} / \mathrm{m}^{2}$ & 施行令を参考 \\
\hline
\end{tabular}

(外壁・内壁は壁長さ $1 \mathrm{~m}$ あたりの澌量, その他は床面積 $1 \mathrm{~m}^{2}$ あたりの罂量である)

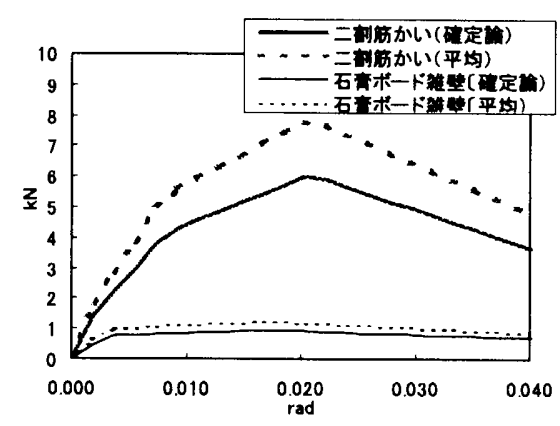

a)壁 $1 \mathrm{~m}$ あたりの骨格曲線

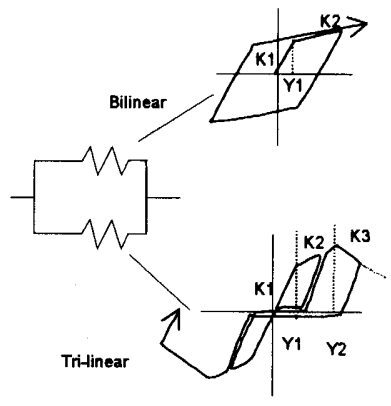

b) 復元力特性モデル

図 4 壁 $1 \mathrm{~m}$ あたりの骨格曲線および復元力特性

表 2 耐力壁と雑壁のパラメーター

（確定論の場合, 壁長さ $1 \mathrm{~m}$ 当たりで表記）

\begin{tabular}{|c|c|c|c|c|c|c|}
\hline \multicolumn{2}{|c|}{} & \multicolumn{3}{|c|}{ 剛性 $(\mathrm{kN} / \mathrm{cm})$} & \multicolumn{2}{c|}{ 降伏変位 $(\mathrm{cm})$} \\
\cline { 2 - 7 } & $\mathrm{K} 1$ & $\mathrm{~K} 2$ & $\mathrm{~K} 3$ & $\mathrm{Y} 1$ & $\mathrm{Y} 2$ \\
\hline \multirow{2}{*}{$\begin{array}{c}\text { 耐 } \\
\text { 壁 }\end{array}$} & Bilinear & 1.80 & 0.10 & & 0.38 & \\
\cline { 2 - 8 } & Tri-linear & 1.47 & 0.46 & -0.56 & 2.25 & 5.63 \\
\hline \multirow{2}{*}{$\begin{array}{c}\text { 雑 } \\
\text { 壁 }\end{array}$} & Bilinear & 0.83 & 0.03 & & 0.23 & \\
\cline { 2 - 7 } & Tri-linear & 0.62 & 0.03 & -0.07 & 0.90 & 4.50 \\
\hline
\end{tabular}


本報では，壁量計算を基とした確定値として計算する際は，図 4 中の “確定論”と記载された復元力特性を用い，ばらつきを考慮し て, 各耐力壁・雑壁の耐力を変化させる場合には, 図 4 中の“平均” と記載された復元力特性を平均値とした復元力特性として用い, 所 定の変動倸数でばらつかせた最大耐力に比例する形で, 耐力方向に 復元力特性を変化させる.

壁量計算に基づいた確定論で用いる設定パラメーターを表 2 に示 す．なお，壁量計算に基づいた確定論では，二割筋かいの骨格曲線 は最大耐力が $5.88 \mathrm{kN} / \mathrm{m}$ 程度が壁倍率(2.0)から妥当である(壁倍率 2.0 では, $1.96 * 2.0 * 1.5=5.88 \mathrm{kN}$ 程度が下限值と想定した）と判断した. また, 石育ボード雑壁の場合, 石高ボード雑壁の壁倍率を 0.5 として 5), 石育ボード雑壁の最大耐力は $1 \mathrm{kN} / \mathrm{m}$ 程度が妥当と考えた.

壁耐力のばらつきは, 最大耐力で代表させる. 各耐力壁の変動は, 文献 3)を参考に, 最大耐力を平均 $8 \mathrm{kN}$ 変動係数 0.3 として正規分布 で設定最大耐力を生成している. 耐力壁の復元力特性は, 先にも述 べたように，図 4 中の（平均）と記載された復元力特性を耐力方向 に増減させ，最大耐力 $(8 \mathrm{kN})$ を各耐力壁の設定最大耐力に一致させる。

雑壁の最大耐力の平均は $1.3 \mathrm{kN}$ と仮定した（設定理由は, 注を参 照）。なお，雑壁の耐力分布特性は不明であるが，耐力壁のばらつ きを準用し, 変動係数を 0.3 とした. 個々の雑壁の復元力特性は, 耐 力壁の場合と同様に, 図 4 の復元力特性 (平均) を耐力方向に增堿 させ, 最大耐力を各雑壁の設定最大耐力に一致させる.

\section{3 地罢応答解析}

応答解析に用いる地震動波形は，日本建築センターで配布してい る地震動加速度波形の内，ELCENTNS（以下，エルセントロNS）， HACHINNS（以下，八戸 NS）, TAFTEW（以下，タフトEW）, 兵庫 県南部地震神戸海洋気象台波 NS 成分（以下，JMA 神戸 NS），兵庫 県南部地震鷹取波 NS 成分（以下，鷹取 NS）を最大地動速度（以下, $\mathrm{PGV）を} 50 \mathrm{~cm} / \mathrm{s}$ に変換したものを使用した。数值積分には, 中間加 速度法を用い，時間刻み 0.005 秒で計算している。

一般の木造軸組建物では, 1 階の最大層間変位が 2 階の最大層間 変位に卓越するため，本報で論じる最大変位応答は 1 階のねじり振 動も考慮した最大層間変位応答とする.

减衰定数は, 初期剛性比例 3\%と設定した.

\section{4 使用する既存建物の充足率}

本報で使用した建物の充足率 (二耐力壁量/表 3 の所用有效壁量) の分布，耐力壁の壁量より算定した 1 階偏心率の分布を図 5 に示す. 以下，本報では耐力壁の壁量より算定した 1 階偏心率を偏心率之称 する. 本建物群は既報 6 )で用いた 2 階建て在来軸組構法木造住宅の 内の 208 棟である. なお当該建物の床の種類は不明である.本報で は建物の梁間・桁行を考慮せずに各方向とも計算時のサンプルとす る. 従って, 計算のサンプル数は 416 となる，1階充足率の平均は $1.67 ， 2$ 階充足率の平均 $1.90 ， 1$ 階偏心率の平均は 0.16 である。 ま た，図より，1 階充足率より 2 階充足率が高いこと， 1 階偏心率と 1 階充足率に相関が低いことが分かる，以下， 1 階充足率のことを 充足率と呼ぶ。

なお、本報で使用した建物データの中には，二割筋かい以外に一 部三割筋かい耐力壁が含まれているが，耐力壁量が同量になるよう に二割筋かいに設計変更した。
䘚 3 所用有効壁長 $(m)^{5}$ )

\begin{tabular}{|l|c|c|}
\hline & 1 階 & 2 階 \\
\hline 軽い屋根 & $0.11 \mathrm{~A}_{1}+0.18 \mathrm{~A}_{2}$ & $0.15 \mathrm{~A}_{2}$ \\
\hline 重い屋根 & $0.15 \mathrm{~A}_{1}+0.18 \mathrm{~A}_{2}$ & $0.21 \mathrm{~A}_{2}$ \\
\hline
\end{tabular}

$A_{1}, A_{2}$ : それぞれ 1 階, 2 階の床面積 $\left(\mathrm{m}^{2}\right)$

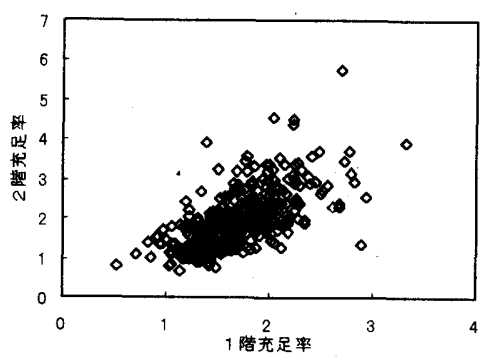

a) 充足率の分布

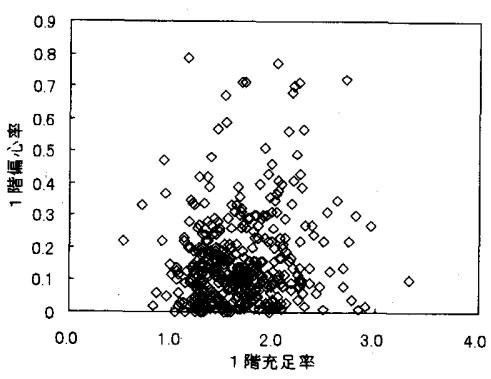

b) 1 階充足率と偏心率の関保

図 5 使用した建物の充足率と偏心率の分布

\section{3. 結果と分析}

\section{11 建物におけるばらつき}

本節では図 3 の建物の南北方向の保有水平耐力と最大変位応答の 分布を検討する. この建物の南北方向の充足率は 1.88 で，偏心率は 0.40 である. 図 6 に壁量計算に基づいた確定論で得られた保有水平 耐力に対する壁耐力のばらつきを考慮した場合の保有水平耐力の比 の分布を示す．保有水平耐力の平均は，壁量計算に基づいた確定論 で計算された値の 1.33 倍であり，変動俰数は 0.059 である.これは， 壁量計算に基づいた確定論で用いた復元力特性の 1.3 倍の復元力特 性を平均値としているためと考えられる。また，壁量計算に基づい た確定論で得られた保有水平耐力に対する壁耐力のばらつきを考虑 した保有水平耐力の比の下限値は，1.0を超えており，壁量計算に基 づいた確定論を用いて保有水平耐力を計算すれば，壁耐力のばらう きを考慮した場合の保有水平耐力分布の下限を満足すると言える。

図 7 に壁量計算に基づいた確定論で得られた最大変位応答に対す る対する壁耐力のばらつきを考慮した場合の最大変位応答の比（以 下, “最大変位态答比”と称す）の分布を示す. 図より, 地震動に 対する最大変位忘答のほとんどは，壁量計算に基づいた確定論によ り得られた最大変位応答より小さく，壁量計算に基づいた確定論で 最大変位応答を計算すれば, 最大変位応答分布の上限を満足するこ とが分かる.しかし，一部の地震動（タフト EW(taew50),八戸 NS(hans50)）に対する最大変位応答の多くが, 壁量計算に基づいた確 定論で得られる最大変位応答より大きくなるので注意が必要である. 表 4 に各地震動における最大変位応答比の平均と変動保数を示寸. 表より, 最大変位応答比の平均は, $0.7 \sim 0.9$ の間にあり, 最大変位応 答比の変動係数は 0.1 前後の値となっている. しかし, この建物の場 
合では，どの地震動で計算した場合でも，壁量計算に基づいた確定 論で得られた最大変位応答の 1.3 倍程度の最大変位応答を考えてお く必要があることが図より読みとれる。

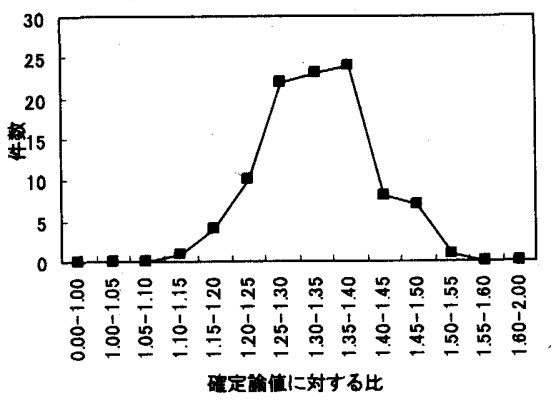

图 6 壁量計算に基づいた確定論で得られる保有水平耐力に対する 壁耐力のばらつきを考慮した場合の保有水平耐力の比の分布

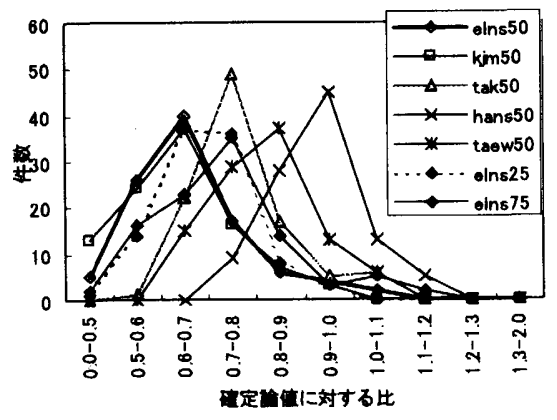

因 7 壁量計算に基づいた確定論で得られる最大変位志答に対する 壁耐力のばらつきを考盧した場合の最大変位态答の比の分布 （図中の記号は表 4 参照）

表 4 図 3 の建物におけ壁量計算に基づいた確定論で得られる最 大変位応答に対する壁耐力のばらつきを考虚した場合の最大変位応 答の平均と変動保数

\begin{tabular}{|c|c|c|c|}
\hline \multicolumn{2}{|l|}{ 地震動 } & 平均 & 変動係数 \\
\hline エルセントロ $\mathrm{NS}(\mathrm{PGV}=50 \mathrm{~cm} / \mathrm{s})$ & :elns50 & 0.67 & 0.121 \\
\hline JMA 神戸 $N S(P G V=50 \mathrm{~cm} / \mathrm{s})$ & :kjm50 & 0.64 & 0.124 \\
\hline 鷹取 NS(PGV=50cm/s) & :tak50 & 0.77 & 0.100 \\
\hline 八戸 $\mathrm{NS}(\mathrm{PGV}=50 \mathrm{~cm} / \mathrm{s})$ & hans 50 & 0.93 & 0.091 \\
\hline タフト $\mathrm{EW}(\mathrm{PGV}=50 \mathrm{~cm} / \mathrm{s})$ & :taew50 & 0.82 & 0.105 \\
\hline エルセントロ $\mathrm{NS}(\mathrm{PGV}=25 \mathrm{~cm} / \mathrm{s})$ & :elns25 & 0.70 & 0.095 \\
\hline エルセントロ $\mathrm{NS}(\mathrm{PGV}=75 \mathrm{~cm} / \mathrm{s})$ & :elns75 & 0.73 & 0.137 \\
\hline
\end{tabular}

\section{2 建物群でのばらつき}

本節では，前節で行った解析を 208 棟の建物群に対して行い, 建 物群としての壁量計算に基づいた確定論で得られる保有水平酎力・ 最大変位応答に対する壁耐力のばらつきを考慮した場合の保有水平 耐力・最大変位応答の比のばらつきを検討する.

図 8 に, “208棟の各建物”の壁量計算に基づいた確定論で得られ る保有水平耐力に対する壁耐力のばらつきを考慮した保有水平耐力 の比の平均值, 変動倸数, 最大值・最小值, $95 \%$ 区閒の最大 ・最小 （平均 $\pm 1.96 \times$ 標準偏差）を充足率をパラメーターにして示す. 図よ り，各建物においても，保有水平耐力の平均値は，壁量計算に基づ いた確定論で計算される值の 1.3 倍程度になっていることが分かる。 これは，前節で述べたように壁量計算に基づいた確定論で得られる
最大耐力の 1.3 倍の最大耐力を平均值として与えているためである. また，最小值の分布も壁量計算に基づいた確定論で得られる保有水 平耐力の 1.0 倍以上, $95 \%$ 区間の最小値の分布も壁量計算に基づいた 確定論で得られる保有水平耐力の 1.1 倍以上となっており, 保有水平 耐力を計算する祭には, 壁量計算に基づいた確定論で計算すれば, 壁耐力のばらつきを考慮した場合の保有水平耐力分布の下限を満足 することになる.

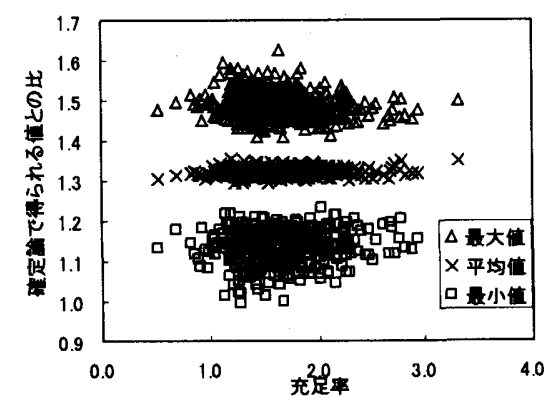

a) 平均値 ·最大値・最小値の確定論値との比

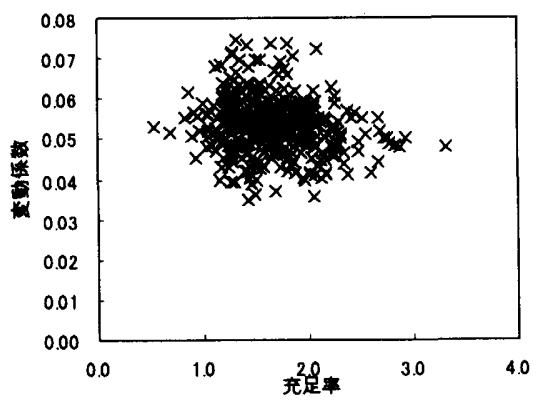

b) 変動係数の分布

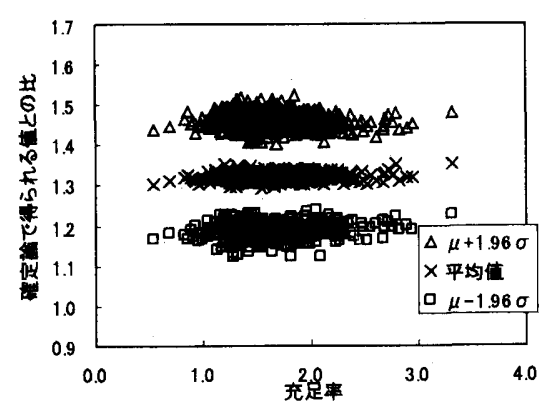

c) $95 \%$ 区閒の最大 ・ 最小 (平均土 $1.96 \times$ 標準偏差)と確定論值の比

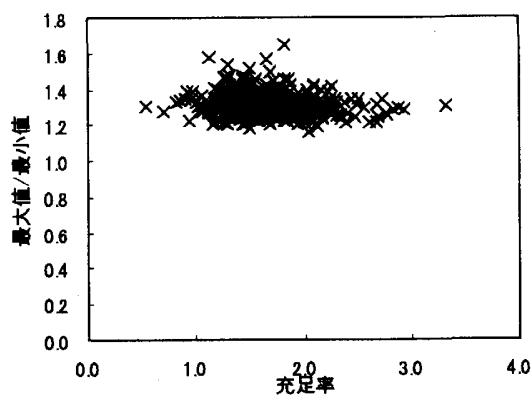

d) 最大值/最小値の分布

図 8 壁量計算に基づいた確定論で得られる保有水平耐力に対する 壁耐力のばらつきを考慮した場合の保有水平耐力の比の分布 一方, 変動係数は 0.05 近辺を中心に分布している. 保有水平耐力の 
最大值と最小値の比は，1.3を中心に分布している．平均值・標準偏 差などの各值は，充足率に無関係と言える. 図 9 に充足率と保有水 平耐力の関倸を示す，明らかに壁量計算に基づいた確定論で計算さ れた分布より，壁耐力のばらつきを考慮して計算した場合の方が， 同じ充足率でも保有水平耐力のばらつきが大きい，

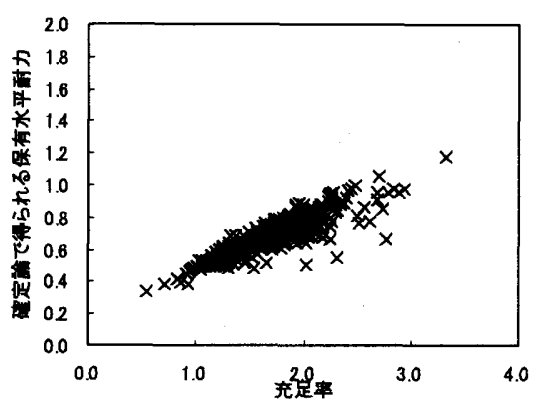

a) 壁量計算に基づいた確定論で計算した場合

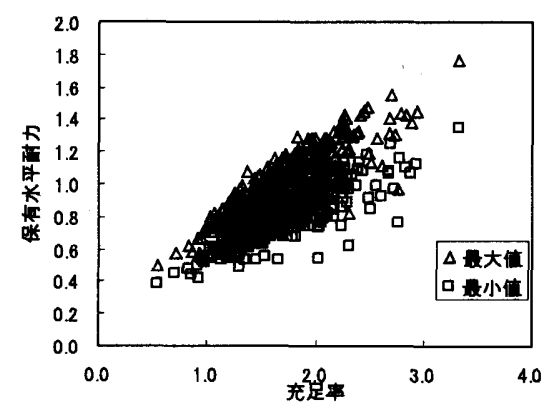

b）壁耐力のばらつきを考慮した場合の最大值と最小値 図 9 充足率之保有水平耐力の関倸

図 10 にエルセントロ波 NS成分 $\mathrm{PGV}=50 \mathrm{~cm} / \mathrm{s}$ の場合における“208 棟の各建物”の壁量計算に基づいた確定論により得られた最大変位 応答に対する壁耐力のばらつきを考慮した場合の最大変位応答の比 を示す，図中の縦軸は，壁量計算に基づいた確定論で得られた最大 変位応答に值に対する最大変位応答比（“最大変位応答比”）の平 均値, 変動係数, 最大值 - 最小値, $95 \%$ 区間の最大 - 最小（平均士 $1.96 \times$ 標準偏差）を示し，横軸は充足率を示す．図より，各建物にお いても, 最大変位応答比の平均値は, 0.7 程度になっていることが分 かる. 最大変位応答比の変動係数は 0.12 近辺を中心に分布している. また, 最大変位応答比の最小值の分布も 0.5 付近を中心に分布し, 最 大変位応答比の最大值も 0.9 付近を中心に分布しており，一部 1.0 以 上となっているケースが見られる．最大変位応答比の $95 \%$ 区間の最 大值（平均 $+1.96 \times$ 標準偏差）は，ほぼ 1.0 倍以下であり，このケー ス（エルセントロ波 $\mathrm{NS}$ 成分 $\mathrm{PGV}=50 \mathrm{~cm} / \mathrm{s}$ ）では，壁量計算に基づい た確定論で計算しても問題は無いと言える，一方，ばらつきを考慮 した場合における各建物ごとの最大変位応答の最大値と最小值の比 は，1.8を中心に分布している.

図 11 に充足率と壁耐力のばらつきを考慮した場合の最大変位応 答の関係を示す，明らかに確定論で計算された分布より，壁耐力の ばらつきを考慮して計算した場合の方が，同じ充足率でも最大変位 応答のばらつきが大きい，特に，充足率が低い場合は, 最大変位応 答が大きい場合が多く, 最大変位応答のばらつきの範囲も広いため,

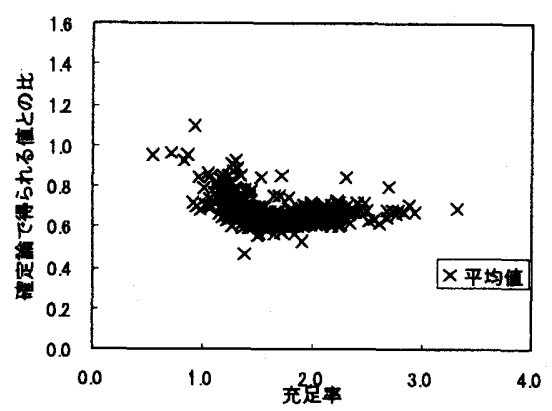

a) 平均値の確定論值との比

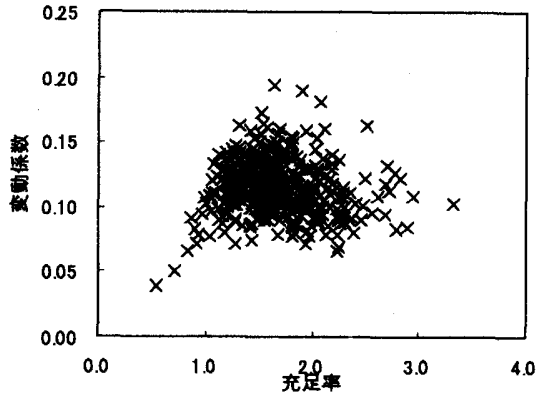

b) 変動係数の分布

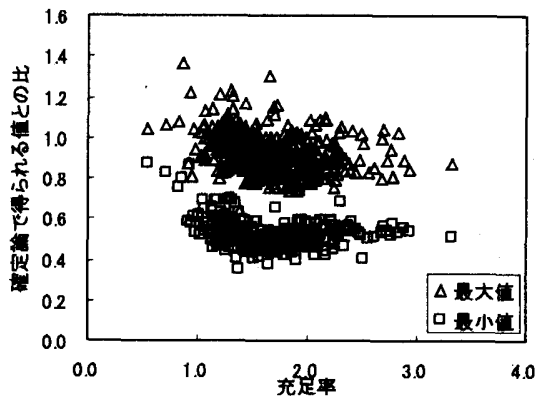

c) 最大值・最小値の確定論値との比

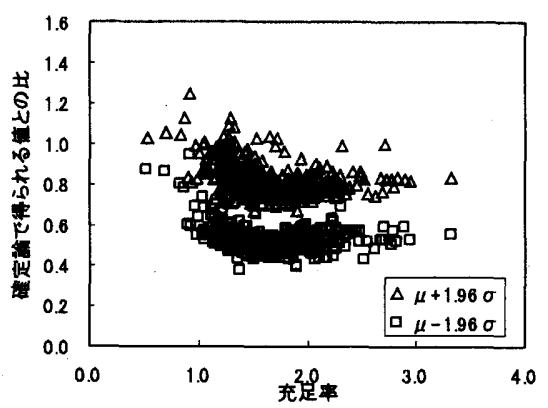

d) $95 \%$ 区間の最大 ・ 最小 $($ 平均 $\pm 1.96 \times$ 標準偏差 $)$ と確定論值の比

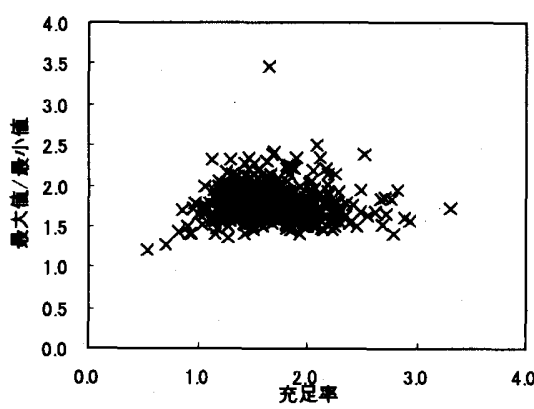

e) 最大値/最小值の分布

図 10 壁量計算に基づいた確定論で得られる最大変位応答に対す る壁耐力のばらつきを考慮した場合の最大変位応答の比の分布

(エルセントロ波 $\mathrm{NS}$ 成分, $\mathrm{PGV}=50 \mathrm{~cm} / \mathrm{s}$ ) 
充足率と建物被害の関保づけが難しいことが分かる.

表 5 に各地慶動における壁量計算に基づいた確定論で得られる最 大変位応答に対する壁耐力のばらつきを考慮した場合の最大変位応 答の比の個々の建物における平均と変動倸数を, 建物群としての平 均をとった值を示す. 変動係数の平均值は 0.1 前後であるが, 最大変 位応答比の平均は, 地震動により, 大きく変動する.

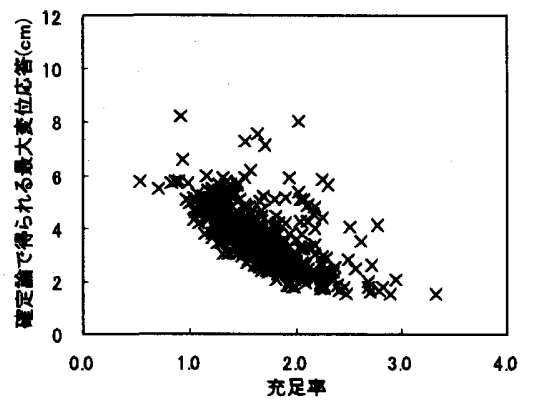

a）壁量計算に基づいた確定論で計算した場合

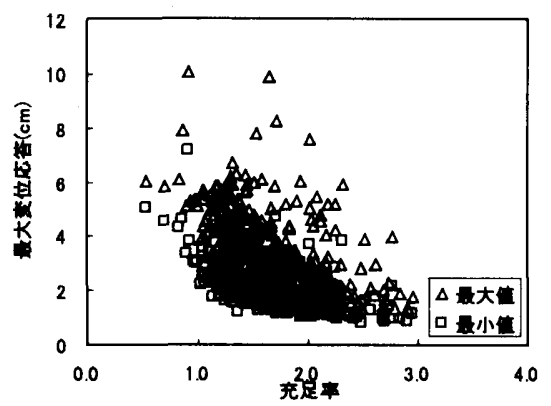

b) 壁耐力のばらつきを考虑した場合の最大值と最小值

因 11 充足率と最大变位芯答の関倸 (エルセントロ波 $\mathrm{NS}$ 成分, $\mathrm{PGV}=50 \mathrm{~cm} / \mathrm{s}$ )

衣 5 各建物における壁量計算に基づいた確定論で得られる最大変 位応答に対する最大変位応答の平均と変動係数の建物群としての平 均

\begin{tabular}{|l|c|c|}
\hline \multicolumn{1}{|c|}{ 地蜄動 } & $\begin{array}{l}\text { 各建物平均 } \\
\text { 檤の平均 }\end{array}$ & $\begin{array}{l}\text { 各建物変動係 } \\
\text { 数の平均 }\end{array}$ \\
\hline エルセントロ $\mathrm{NS}(\mathrm{PGV}=50 \mathrm{~cm} / \mathrm{s})$ & 0.674 & 0.114 \\
\hline $\mathrm{JMA}$ 神戸 $\mathrm{NS}(\mathrm{PGV}=50 \mathrm{~cm} / \mathrm{s})$ & 0.645 & 0.129 \\
\hline 鷹取 $\mathrm{NS}(\mathrm{PGV}=50 \mathrm{~cm} / \mathrm{s})$ & 0.785 & 0.095 \\
\hline 八戸 $\mathrm{NS}(\mathrm{PGV}=50 \mathrm{~cm} / \mathrm{s})$ & 0.929 & 0.090 \\
\hline タフト $\mathrm{EW}(\mathrm{PGV}=50 \mathrm{~cm} / \mathrm{s})$ & 0.800 & 0.099 \\
\hline エルセントロ $\mathrm{NS}(\mathrm{PGV}=25 \mathrm{~cm} / \mathrm{s})$ & 0.700 & 0.116 \\
\hline エルセントロ $\mathrm{NS}(\mathrm{PGV}=75 \mathrm{~cm} / \mathrm{s})$ & 0.755 & 0.115 \\
\hline
\end{tabular}

壁量計算に基づいた確定論で得られる最大変位応答に対する壁耐 力のばらつきを考虐した場合の最大変位応答の比（最大変位応答比） の平均が大きい代表例として, 図 12 に八戸 $\mathrm{NS}(\mathrm{PGV}=50 \mathrm{~cm} / \mathrm{s})$, 図 1 3 にエルセントロ $\mathrm{NS}(\mathrm{PGV}=75 \mathrm{~cm} / \mathrm{s})$, 図 14 にエルセントロ $\mathrm{NS}(\mathrm{PGV}=25 \mathrm{~cm} / \mathrm{s})$ で計算した事例を示す。図より，八戸 $\mathrm{NS}(\mathrm{PGV}=50 \mathrm{~cm} / \mathrm{s})$ では，充足率に関係なく，最大変位応答比が大きく 出ているのに対して，エルセントロ $\mathrm{NS}(\mathrm{PGV}=75 \mathrm{~cm} / \mathrm{s})$ では，充足率が 小さい場合に, 最大変位芯答比が大きく出ている. また, エルセン トロ NS $(\mathrm{PGV}=25 \mathrm{~cm} / \mathrm{s})$ の場合では，充足率が大きい場合に，最大変位 応答比が大きく出ている。
以上をまとめると，壁量計算に基づいた確定論で得られる最大変 位応答に対する最大変位応答の比の分布は, 地震動の種類・大きさ に大きく依存しており，本報での計算結果の範囲では，定量的な判 断が不可能である.しかし，PGV=50cm/s の範囲で云えば，壁量計算 に基づいた確定論で計算される 1.2 1.4 倍程度の変形能力を確保し ていれば良いと判断できる.

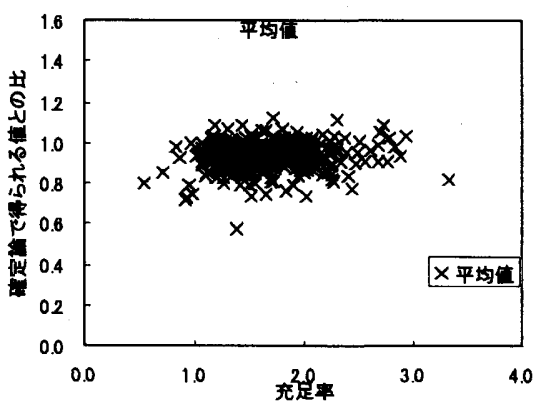

a) 平均值の確定論值との比

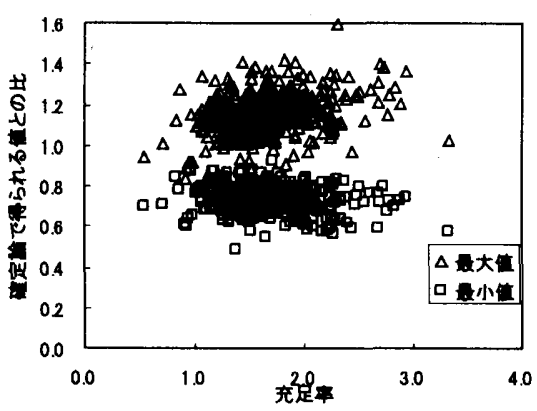

b) 最大值・最小值の確定論值との比

图 12 壁量計算に基づいた確定論で得られる最大変位応答に対す る壁耐力のばらつきを考虑した場合の最大変位応答の比の分布 (八戸波 NS 成分, $\mathrm{PGV}=50 \mathrm{~cm} / \mathrm{s}$ )

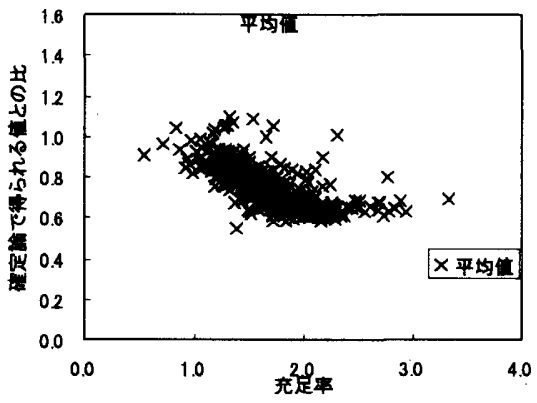

a) 平均值の確定論値との比

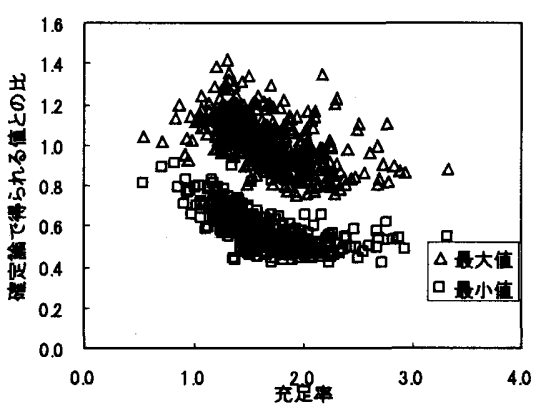

b) 最大值・最小值の確定論值との比

図 13 壁量計算に基づいた確定論で得られる最大変位応答に対す る壁耐力のばらつきを考慮した場合の最大変位応答の比の分布 (エルセントロ波 NS 成分, $\mathrm{PGV}=75 \mathrm{~cm} / \mathrm{s}$ ) 


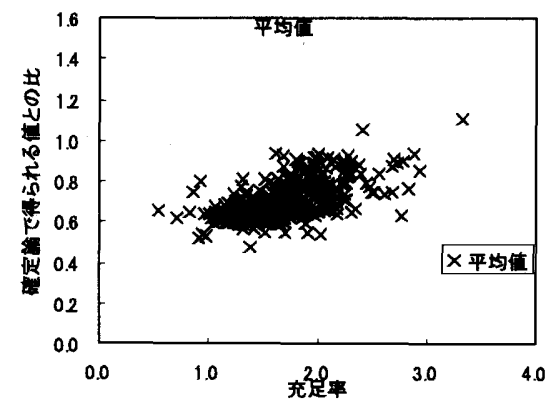

a) 平均值の確定論値との比

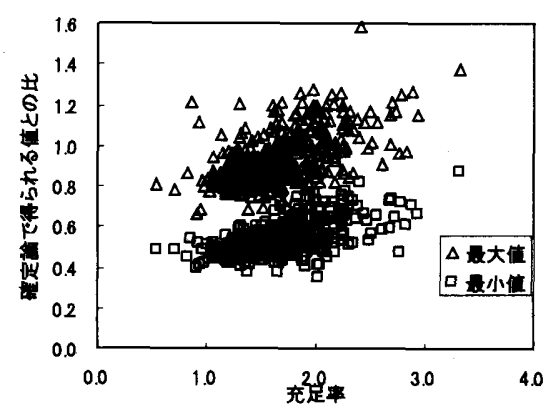

b) 最大値・最小値の確定論值との比

図 14 壁量計算に基づいた確定論で得られる最大変位応答に対す る壁耐力のばらつきを考慮した場合の最大変位応答の比の分布

(エルセントロ波 $\mathrm{NS}$ 成分, $\mathrm{PGV}=25 \mathrm{~cm} / \mathrm{s}$ )

\section{6. 結語}

本報では，複数の建物モデルに対して，耐力壁・雑壁の壁毎の耐 力ばらつきを考慮して保有水平耐力・最大変位応答を計算し, 壁量 計算に基づいた確定論による解析值と比較検討した。その結果，以 下の事項が判明した.

・耐力ばらつきを考慮した場合の保有水平耐力の分布は, 壁量計算 に基づいた確定論による保有水平耐力の值以上となるので，壁量 計算に基づいた確定論により計算すればよい。

・壁量計算に基づいた確定論による最大変位応答値に对する耐力ば らつきを考慮した場合の最大変位応答の比の分布は, 地震動の種 類・大きさに大きく伡存しており，本報の範囲では定量的な判断 が不可能である. しかし，最大地動速度 $50 \mathrm{~cm} / \mathrm{s}$ の範囲でいえば， 壁量計算に基づいた確定論で計算される 1.2 1.4 倍程度の変形能 力を確保していれば良いことが分かる。

\section{解辞}

本研究の一部は, 文部科学省科学研究費補助金・若手研究(B)（課 題番号 15760434）により行われた．また，名古屋大学情報連携基盤 センターの汎用サーバーを用いて計算を行った. 記して謝意を示す.

\section{参考文献}

1) 山田耕司:木造住宅の保有水平耐力分布とその推定法，日本建筑学会技術報 告集 第 18 号,pp.91-96,2003

2) 山田耕司:床剛性と雑壁を考虑した木造軸組建物の最大変位応答分布, 日本 建策学会権造系論文集 第 586 号, pp. -, 平成 16 年 12 月

3）山田耕司，後藤正美:筋かい耐力壁復元力特性のぼらつきと地震応答のばら つき，樓造工学諭文集 Vol. 50. B，pp. 327-333，2004.3

4）河合直人, 岡部実, 渡辺一正 : 在来軸租粠法耐力壁の耐震性能 その 2 仮 動的試雅，日本建策学会大会学術譵演梗概集（九州），pp.135-136，1998

5) 建設省住宅局 : 木造住宅の耐鹿精密診断と補強方法,1985

6) 山田耕司: 愛知県の在来軸租木造住宅の壁量に関する調查研究，構造工学諭 文集 Vol.46.B, pp.181-188., 2000

7) 村上雅英,䄯㴞山正弘: 任意の鲀配列で打たれた面材壁の弾塑性举動の予测式, 日本建築学会權造系馀文集,No.519,pp.87-93,1999

8) 日本建築学会 : 建筑耐震設計における保有耐力と変形性能 $1981, \mathrm{p} .41,1981$

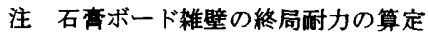

石亮ボード雓壁および耐力壁の終局耐力を以下の仮定に基つき文献 クに沿

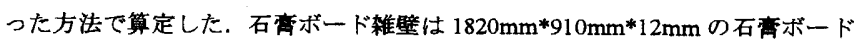
が@450mm で付図 1 のように下地（柱のみ）にビスで固定されているものと

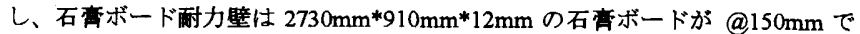
柱のみにビスで固定されているものと仮定した，石亮ボードのビス接合一面せ ん断の骨格曲線を付図 2 とした場合, 付図 3 のように耐力壁の終局耐力が 5.92 $\mathrm{kN}$ ，雓壁の終局耐力が $1.19 \mathrm{kN}$ と計算される。なお、柱の曲げ変形恃考虑して いない，文献 8)中の石亮ボード耐力壁の最大耐力が $6 \mathrm{kN}$ 程度であるので，本 仮定は適切と判断した. また， $1 \mathrm{~m}$ 当たりにすると，1.2/0.9=1.33 となるので，

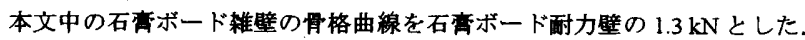

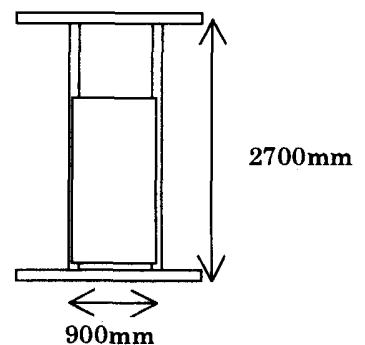

付図 1 想定モデル

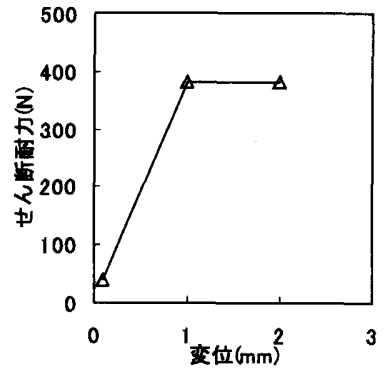

付图 2 石育ボードのビス接合 一面せん溯骨格曲線

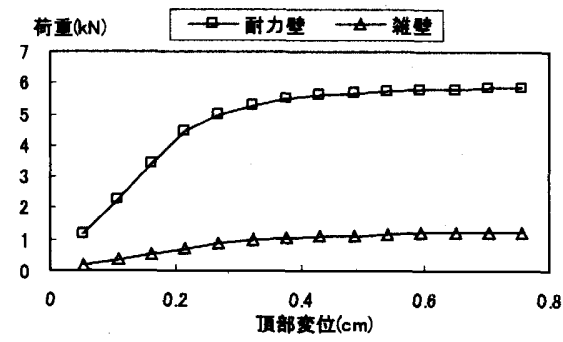

付図 3 石青ボード耐力壁および雑壁の復元力特性計算值 